\title{
Physical quality of an Oxisol under no-tillage subjected to different cropping systems
}

\author{
Getulio de Freitas Seben Junior ${ }^{(1)}$, José Eduardo Corá(2) and Rattan Lal(3)
}

\begin{abstract}
(1)Universidade do Estado de Mato Grosso, Faculdade de Ciências Biológicas e Agrárias, Rodovia MT 208, Km 147, Jardim Tropical, CEP 78580-000 Alta Floresta, MT, Brazil. E-mail: getulioseben@unemat.br (2)Universidade Estadual Paulista Júlio de Mesquita Filho, Faculdade de Ciências Agrárias e Veterinárias, Campus de Jaboticabal, Via de Acesso Prof. Paulo Donato Castellane, s/no, CEP 14884-900 Jaboticabal, SP, Brazil. E-mail: cora@fcav.unesp.br ${ }^{(3)}$ Ohio State University, 2021 Coffey Road, 43210, Columbus, OH, USA. E-mail: lal.1@osu.edu
\end{abstract}

\begin{abstract}
The objective of this work was to evaluate the physical quality of an Oxisol under no-tillage subjected to different crop rotations and crop sequences. The experiment was carried out in a clayey Oxisol, during six years, in a randomized complete block design, with strip plots and three replicates. The following physical indicators of soil quality were evaluated: soil density and carbon content, as well as mean weight diameter and tensile strength of aggregates. Treatments consisted of three summer crop rotations - corn/ corn (Zea mays), soybean/soybean (Glycine max), and soybean/corn - and of seven second crops (crop sequences) - corn, sunflower (Helianthus annuus), oilseed radish (Raphanus sativus), pearl millet (Pennisetum americanum), pigeon pea (Cajanus cajan), grain sorghum (Sorghum bicolor), and sun hemp (Crotalaria juncea). Crop rotations and sequences did not affect soil carbon contents. Corn, as a summer crop, increased the tensile strength and mean weight diameter of aggregates, similarly to pearl millet and sorghum as second crops. Soybean/corn rotation with sun hemp as a second crop increases soil physical quality, promoting higher tensile strengths and lower soil densities.
\end{abstract}

Index terms: carbon sequestration, crop rotation, diameter of aggregates, soil density, soil organic carbon, tensile strength.

\section{Qualidade física de Latossolo sob plantio direto submetido a diferentes sistemas de cultivo}

Resumo - O objetivo deste trabalho foi avaliar a qualidade física de Latossolo sob plantio direto submetido a diferentes rotações de cultura e cultivos de sucessão. O experimento foi realizado em Latossolo Vermelho eutrófico argiloso, durante seis anos, em delineamento de blocos ao acaso, em faixa, com três repetições. Foram avaliados os seguintes atributos físicos, indicadores da qualidade do solo: densidade do solo e conteúdo de carbono, bem como diâmetro médio ponderado e resistência tênsil dos agregados. Os tratamentos consistiram de três rotações com culturas de verão - milho/milho (Zea mays), soja/soja (Glycine max) e soja/milho - e de sete segundos cultivos (sucessão) - milho, girassol (Helianthus annuus), nabo forrageiro (Raphanus sativus), milheto (Pennisetum americanum), feijão-guandu (Cajanus cajan), sorgo (Sorghum bicolor) e crotalária (Crotalaria juncea). As rotações e os cultivos de sucessão não influenciaram o conteúdo de carbono no solo. $\mathrm{O}$ milho, como cultivo de verão, incrementou a resistência tênsil e o diâmetro médio ponderado dos agregados, do mesmo modo que o milheto e o sorgo como segundos cultivos. A rotação soja/milho, com crotalária como segundo cultivo, aumenta a qualidade física do solo e promove maior resistência tênsil e menor densidade do solo.

Termos para indexação: sequestro de carbono, rotação de culturas, diâmetro de agregados, densidade do solo, carbono orgânico do solo, resistência tênsil.

\section{Introduction}

Soil physical quality is strictly related with its organic carbon content, and reductions in this attribute often decrease crop productivity and enhance soil vulnerability to physical degradation.
No-tillage systems can potentially reverse soil degradation in tropical regions and, with the intensification and proper use of crop sequences, it can also increase soil organic carbon (SOC). Sá et al. (2013) reported SOC increases of $0.67 \mathrm{Mg} \mathrm{ha}^{-1}$ per year by reducing soil disturbance with no-tillage, which can 
also lead to soil aggregation, reduced soil density, and greater least limiting water range (Seben Junior et al., 2014).

The benefits of the proper use of crop sequences to the soil vary according to the diversity of the species used in the cropping system. Crop sequence arrangements with greater species diversity, for example, can improve SOC by $1.30 \mathrm{Mg} \mathrm{ha}^{-1}$ per year (Sá et al., 2013), increase biopores and the tensile strength of soil aggregates (Tormena et al., 2008), improve aggregate size (Martins et al., 2009), decrease soil density, and increase macro- and total porosity (Spera et al., 2009). However, information on which cropping system can promote more benefits to soil physical quality in tropical regions is still needed for a better adjustment to environmental specificities.

In the Brazilian Southeast, one of the most limiting factors for a greater addition of plant biomass to the soil is the restricted growth of crops during the fall and winter, imposed by the hot and dry weather of these seasons in the region. Among the options for second crops in tropical regions, sun hemp (Crotalaria juncea L.), pigeon pea [Cajanus cajan (L.) Millsp.], and oilseed radish (Raphanus sativus L.) are well known and used as cover crops due to their high production of biomass $\mathrm{C}$ and $\mathrm{N}$, with low C:N ratio. Pearl millet [Pennisetum americanum (L.) K.Schum] is also commonly used as a cover crop in the country. Sunflower (Helianthus annuus L.), corn (Zea mays L.), and sorghum [Sorghum bicolor (L.) Moench], in turn, can be used both as cover and as grain crops. Studying the impacts of diverse/ complex cropping systems under no-tillage is useful for understanding their effects on soil quality.

The objective of this work was to evaluate the physical quality of an Oxisol under no-tillage subjected to different crop rotations and crop sequences.

\section{Materials and Methods}

The experiment was established in 2002 and carried out for six years in the municipality of Jaboticabal, in the state of São Paulo, Brazil (2114' S, 48 $17^{\prime} \mathrm{W}$, at $550 \mathrm{~m}$ of altitude). The climate of the experimental area is Aw according to Köppen's classification, with $70 \%$ relative humidity, mean annual temperature of $22^{\circ} \mathrm{C}$, and mean annual rainfall of $1,425 \mathrm{~mm}$, concentrated between October and March. The soil at the experimental site is classified as a clayey Latossolo
Vermelho eutrófico (Oxisol), based on the Brazilian soil classification system (Santos et al., 2013). Before the establishment of the experiment, the soil had been cultivated with soybean and corn, under conventional tillage, for more than 25 years.

A randomized complete block design was used, with strip plots and three replicates. Each block had 21 plots (crop sequences), consisting of the combination of three summer crop rotations and seven second crops (succession crops). The summer crops were grown between November and March, and were repeated every year in the same plots. The tested rotations were: corn/corn, corn monoculture; soybean/soybean, soybean monoculture; and soybean/corn rotation. The following succession crops were sown in March and repeated every year in the same plot: corn, sunflower, oilseed radish, pearl millet, pigeon pea, grain sorghum, and sun hemp.

Sampling was done at the $0.00-0.10-\mathrm{m}$ soil layer, in the sixth year of the experiment. Twenty subsamples of disturbed soil were taken randomly to obtain a composite sample in each plot, using a Dutch auger. Moreover, ten soil monoliths of $0.10 \times 0.20 \times 0.15 \mathrm{~m}$ were also taken from each plot for the structural analysis.

Each soil monolith was wrapped with a plastic film to preserve its structure and moisture content during transportation to the laboratory. In the laboratory, the monoliths were air-dried, at $20^{\circ} \mathrm{C}$, for 24 hours, then broken manually into natural aggregates. From this material, 50 aggregates of $12.5-19.0-\mathrm{mm}$ diameter were selected (Seben Junior et al., 2013), of which 10 were used to determine soil density by the clod method (Grossman \& Reinsch, 2002). Each of the other 40 aggregates was weighed individually and placed at its most stable position for the compressive test, using a digital dynamometer, which was equipped with a linear actuator and load cell of $20 \mathrm{~kg}$ (Figueiredo et al., 2011), and operated at a constant speed of 1.76 $\mathrm{mm} \mathrm{s}^{-1}$. The tensile strength was calculated according to the effective diameter of the aggregate (Dexter \& Kroesbergen, 1985).

From the composite soil sample, two portions were divided: one ( $1 \mathrm{~g})$ to determine SOC content (Yeomans $\&$ Bremner, 1988); and the other, to determine the mean weight diameter (MWD) by wet sieving. The SOC stock $\left(\mathrm{Mg} \mathrm{ha}^{-1}\right)$ was obtained from data on soil bulk densities and SOC contents (Ellert \& Bettany, 1995). The rate of carbon sequestration was calculated

Pesq. agropec. bras., Brasília, v.51, n.9, p.1568-1574, set. 2016 DOI: 10.1590/S0100-204X2016000900056 
by subtracting the SOC content at the establishment of the experiment, in 2002, from the actual SOC contents, divided by the number of experimental years.

The MWD was obtained according to Kemper \& Rosenau (1986), using $40 \mathrm{~g}$ of air-dried aggregates with 4.0-6.3-mm diameter, which were transferred to a nest of sieves with decreasing order of mesh sizes: $4.00,2.00,1.00,0.50,0.25$, and $0.125 \mathrm{~mm}$. The aggregates were directly immersed in water (without pre-wetting), for $15 \mathrm{~min}$, in an apparatus with vertical oscillation adjusted to 31 cycles per min and with an amplitude oscillation of $35 \mathrm{~mm}$. The soil retained on each sieve was transferred to weighted aluminum cans and oven-dried, at $105^{\circ} \mathrm{C}$, for 24 hours. Appropriate correction was made for primary particles of sand or gravel retained on the sieves of $0.5,0.25$, and $0.125 \mathrm{~mm}$ (Kemper \& Rosenau, 1986).

Differences in SOC, carbon stock, rate of $\mathrm{C}$ sequestration, MWD, tensile strength, and soil bulk density were compared with Tukey's test, at 5\% probability, after the analysis of variance.

\section{Results and Discussion}

SOC contents and stocks, as well as rates of $\mathrm{C}$ sequestration, did not differ between the cropping systems (Figure 1). Calonego \& Rosolem (2008) reported that the variation in SOC must be considered in discussions on how crop sequences can increase soil quality, even when differences are not significant. The increases in SOC observed in the present study varied by $0.7 \mathrm{~g} \mathrm{~kg}^{-1}$, between second crops, and by $0.3 \mathrm{~g} \mathrm{~kg}^{-1}$, between summer crops. Increased SOC is closely related with carbon sequestration and can reduce net increase in the atmospheric $\mathrm{CO}_{2}$ load (Bayer et al., 2006).

The rate of $\mathrm{C}$ sequestration in the soil under summer crops ranged from 0.13 to $0.18 \mathrm{Mg} \mathrm{ha}^{-1}$ per year, whereas under second crops, it ranged from 0.11 to $0.21 \mathrm{Mg} \mathrm{ha}^{-1}$ per year (Figure 1). These results are lower than the annual mean rate of $\mathrm{C}$ sequestration for tropical soils under no-tillage system in Brazil, which has been estimated as $0.35 \mathrm{Mg} \mathrm{ha}^{-1}$ per year for the soil layer of $0.00-0.20 \mathrm{~m}$, in the first 10 to 20 years after the adoption of no-tillage systems (Bayer et al., 2006). This result may be attributed to the low quantity of plant biomass added to the soil surface by the second crops, grown during the dry season in the region.
Corn, as a summer crop, in rotation or in monoculture, increased the MWD of aggregates, in comparison with continuous soybean (Table 1). Grasses are more effective in increasing soil aggregation since their root system releases more exudates that promote this attribute, which can physically protect organic materials. Martins et al. (2009), in a study at the same site, verified that continuous corn had the largest aggregates, due to higher contents of SOC, polysaccharides, and easily hydrolysable C. In addition, Martins et al. (2012) found higher MWD in soil with corn as a summer crop, explained by the higher quantities of pentoses, mainly xylose, released from its biomass, when compared with non-grasses.

The MWD increased in soil under pearl millet and grain sorghum successions, in comparison with oilseed radish and pigeon pea (Table 1), and it was also higher under corn and sun hemp. A great MWD can be related to specific root system characteristics and to a large residue production. Increases in soil aggregation by Poaceae species were reported in several studies (Martins et al., 2009, 2012). Garcia \& Rosolem (2010) found that pearl millet and grain sorghum improve soil MWD due to their increased root growth. Martins et al. (2012), in a study in the same area, also observed higher MWD in soil under pearl millet and grain sorghum than under oilseed radish, with intermediate values of the attribute for soil under corn, pigeon pea, sun hemp, and sunflower.

Soil under oilseed radish had the smallest MWD. This result is probably related with the lower quantity of crop residues added to the surface, as well as to their short residence time. Oilseed radish reaches the flowering stage 45 days after germination, when it is cropped and its residues are distributed on soil surface. This contributes to the low quantity of remaining residues after the management, which, according to Crusciol et al. (2005), amounts only to $27 \%$ of the total added 53 days after cropping. Blanco-Canqui \& Lal (2008) found that the removal of $25 \%$ of the corn residues in no-tillage systems decreased the resistance and stability of soil aggregates, probably because of the reduction of cementing agents derived from the residues. Blanco-Canqui \& Lal (2009) also reported that corn residue removal at rates higher than $25 \%$ reduced soil macroaggregates $(>4.75 \mathrm{~mm})$ by $40 \%$, while the removal of $100 \%$ reduced macroaggregates by $60 \%$. 
Summer crop rotations and crop sequences strongly interacted regarding soil tensile strengths (Table 1). For soybean/corn, the highest tensile strength was observed when sun hemp was used as a second crop, instead of oilseed radish or pigeon pea (Table 2). The improvement in soil aggregation by sun hemp may be explained by its vigorous root system and by its capacity to increase soil organic matter (SOM), since
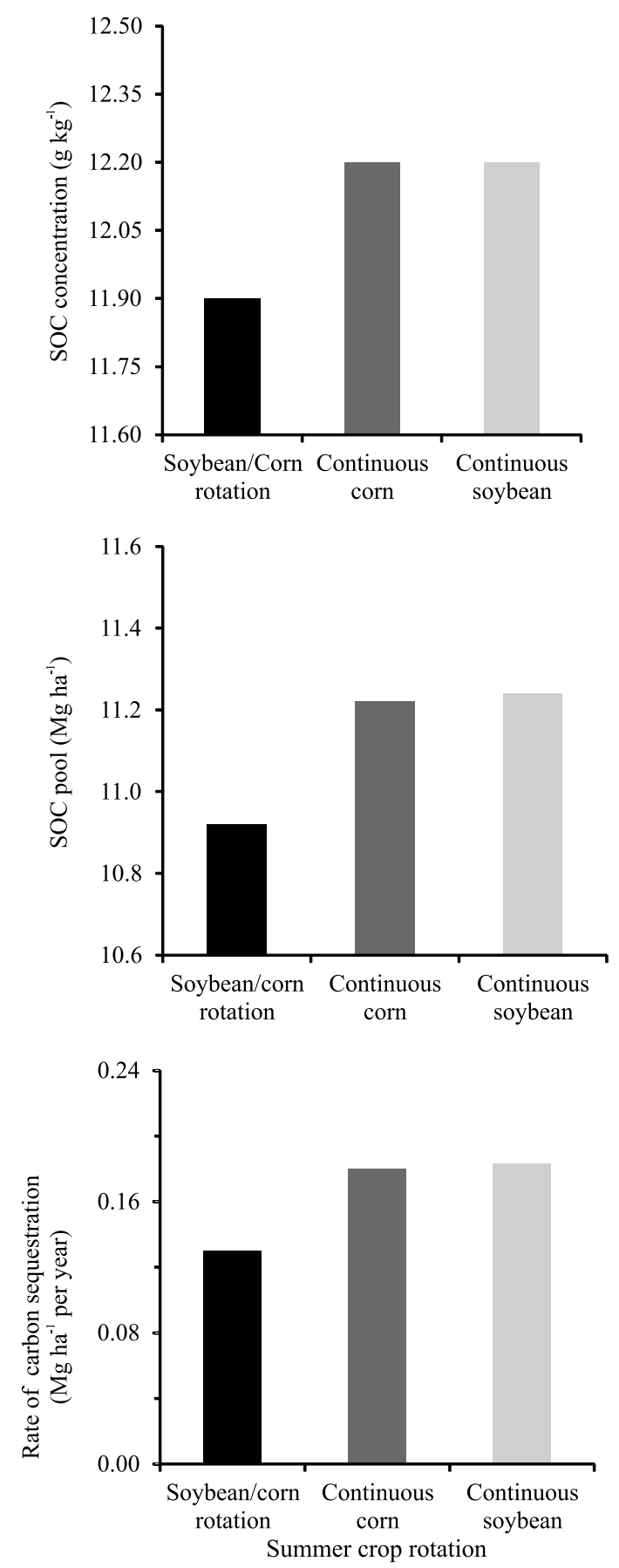
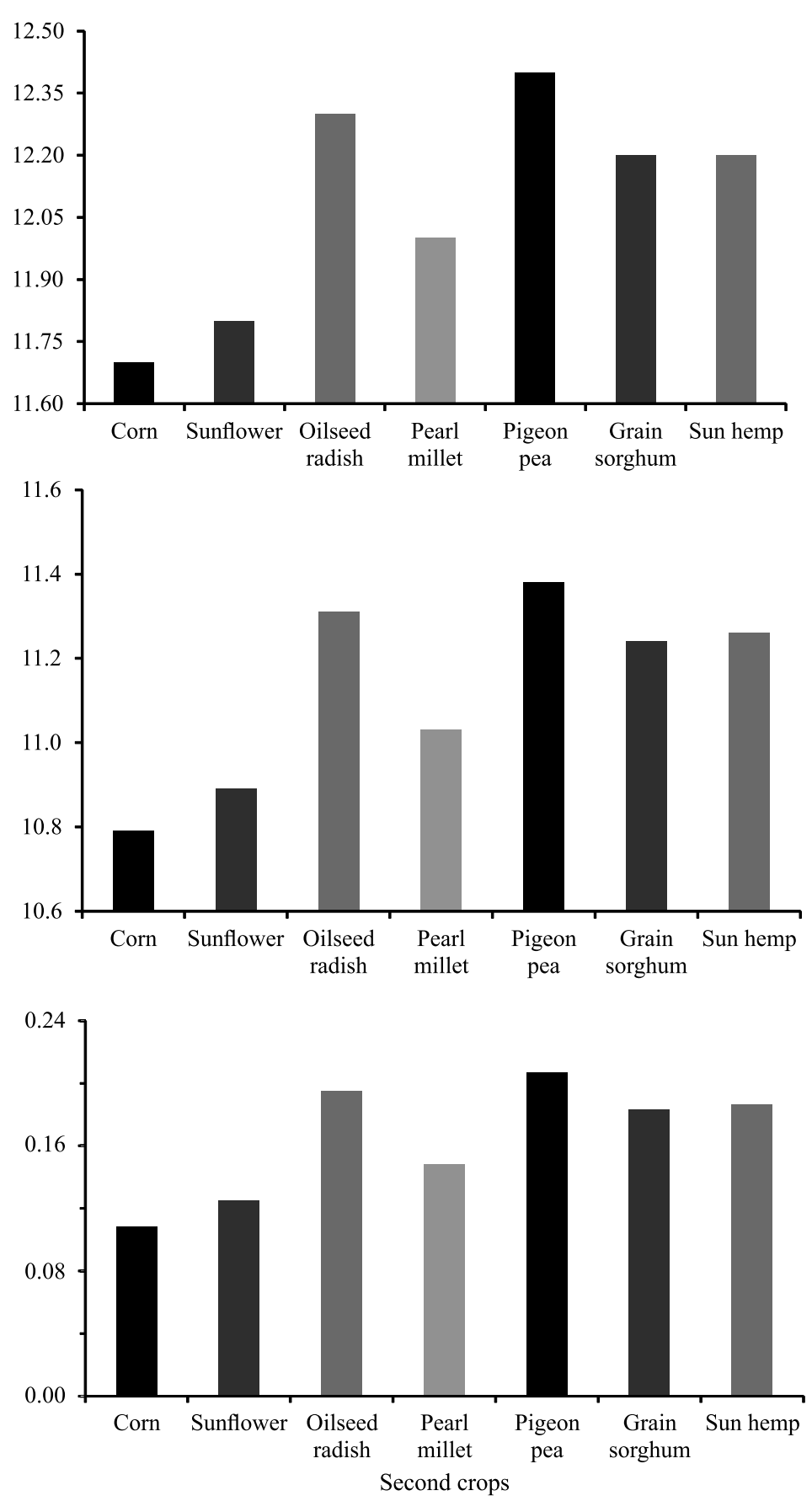

Figure 1. Soil organic carbon (SOC) content and stock, and rate of carbon sequestration as affected by the combination of summer crop rotation arrangements and second crops. Means followed by equal letters do not differ by Tukey's test, at $1 \%$ probability. 
the roots of this species can penetrate the compacted soil layer and create biopores (Foloni et al., 2006). In the same experimental site of the present study, Marcelo et al. (2009) found the highest increase in SOM content, up to the 30 -cm depth, when sun hemp was used, in comparison with other second crops.

The highest tensile strength was observed in soil under sunflower, in combination with soybean/corn rotation, although the values under corn did not differ significantly (Table 2). However, when in combination with continuous soybean, the soil under sunflower had the lowest values of tensile strength. Similar results were obtained for sun hemp, which favored higher tensile strength with soybean/corn rotation than with continuous corn or soybean as summer crops. Crop sequences involving sunflower and sun hemp show the importance of crop rotation arrangements on soil aggregation, considering different families, diverse root systems, and variable residue input and persistence on soil surface; these factors determine soil quality in no-tillage systems. Deep root systems, for example,

Table 1. Mean weight diameter (MWD), tensile strength (TS), and soil bulk density $\left(\ell_{\mathrm{b}}\right)$ of an Oxisol under different no-tillage cropping systems ${ }^{(1)}$.

\begin{tabular}{llcc}
\hline Source of variation ${ }^{(2)}$ & $\begin{array}{c}\text { MWD } \\
(\mathrm{mm})\end{array}$ & $\begin{array}{c}\mathrm{TS} \\
(\mathrm{kPa})\end{array}$ & $\begin{array}{c}\ell_{\mathrm{b}} \\
\left(\mathrm{kg} \mathrm{dm}^{-3}\right)\end{array}$ \\
\hline Summer crop (S) & $3.2 \mathrm{a}$ & 46.7 & 1.5 \\
Soybean/corn rotation & $3.2 \mathrm{a}$ & 41.5 & 1.5 \\
Continuous corn & $2.8 \mathrm{~b}$ & 38.6 & 1.5 \\
Continuous soybean & $6.3^{*}$ & $4.7^{*}$ & $0.3^{\mathrm{ns}}$ \\
\hline F-test & 15.0 & 20.8 & 4.1 \\
\hline CV (\%) & & & \\
\hline Second crop (SC) & $3.2 \mathrm{ab}$ & 43.0 & 1.5 \\
Corn & $3.0 \mathrm{abc}$ & 40.5 & 1.5 \\
Sunflower & $2.7 \mathrm{c}$ & 39.2 & 1.5 \\
Oilseed radish & $3.3 \mathrm{a}$ & 46.2 & 1.4 \\
Pearl millet & $2.8 \mathrm{bc}$ & 38.3 & 1.4 \\
Pigeon pea & $3.3 \mathrm{a}$ & 45.5 & 1.4 \\
Grain sorghum & $3.1 \mathrm{ab}$ & 43.2 & 1.4 \\
Sun hemp & $7.9^{*}$ & $1.5^{\mathrm{ns}}$ & $1.2^{\mathrm{ns}}$ \\
\hline F-test & 8.6 & 17.9 & 4.4 \\
\hline CV (\%) & & & \\
\hline S x SC interaction & $1.3^{\mathrm{ns}}$ & $1.9^{*}$ & $1.8^{*}$ \\
F-test & 8.0 & 14.7 & 2.8 \\
CV (\%) & & & \\
\hline
\end{tabular}

${ }^{(1)}$ Means followed by equal letters do not differ by Tukey's test, at $1 \%$ probability. ${ }^{(2)}$ Soybean, Glycine max; corn, Zea mays; sunflower, Helianthus annuus; oilseed radish, Raphanus sativus; pearl millet, Pennisetum americanum; pigeon pea, Cajanus cajan; grain sorghum, Sorghum bicolor; and sun hemp, Crotalaria juncea. *Significant at $1 \%$ probability.

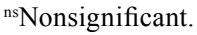

accentuate the effect of wet and dry cycles on soil aggregation, improving it (Ungaro et al., 2005). This is the case of sunflower (Asteraceae), which has a tap root system that can reach up to 2-m depth.

Soil bulk density was significantly affected by the interaction between summer crops and crop sequences (Table 1). With soybean/corn rotation, the second crops oilseed radish, grain sorghum, and sun hemp reduced soil bulk density, when compared with corn (Table 2). For continuous corn, soil bulk density was lower in soil under sun hemp than under sunflower. Oilseed radish, grain sorghum, and sun hemp were mechanically sown with row spacing of $45 \mathrm{~cm}$, whereas sunflower was sown with $90 \mathrm{~cm}$, which probably affected the efficiency of the second crops in reducing or maintaining soil bulk density.

Plots cultivated with sunflower, within soybean/corn rotation, had lower soil bulk density than sunflower with continuous corn as a summer crop. Similar trends were observed for tensile strength, indicating that the increase in soil aggregation decreases soil bulk

Table 2. Tensile strength of soil aggregates and soil bulk density considering the interaction between summer crop rotation arrangements and second crops $^{(1)}$.

\begin{tabular}{|c|c|c|c|c|}
\hline \multirow[t]{2}{*}{ Second crop $^{(2)}$} & \multicolumn{3}{|c|}{ Summer crop $^{(3)}$} & \multirow[t]{2}{*}{ F-test } \\
\hline & $\begin{array}{c}\text { Soybean/corn } \\
\text { rotation }\end{array}$ & $\begin{array}{c}\text { Continuous } \\
\text { corn }\end{array}$ & $\begin{array}{c}\text { Continuous } \\
\text { soybean }\end{array}$ & \\
\hline & \multicolumn{4}{|c|}{ Tensile strength $(\mathrm{kPa})$} \\
\hline Corn & 47.64Aab & $42.58 \mathrm{Aa}$ & 38.86Aa & $1.42^{\mathrm{ns}}$ \\
\hline Sunflower & 48.92Aab & 39.59ABa & $32.92 \mathrm{Ba}$ & $4.72^{*}$ \\
\hline Oilseed radish & $39.53 \mathrm{Ab}$ & $42.41 \mathrm{Aa}$ & $35.53 \mathrm{Aa}$ & $0.87^{\mathrm{ns}}$ \\
\hline Pearl millet & 48.99Aab & $44.65 \mathrm{Aa}$ & $44.93 \mathrm{Aa}$ & $0.43^{\mathrm{ns}}$ \\
\hline Pigeon pea & $38.19 \mathrm{Ab}$ & $35.27 \mathrm{Aa}$ & $41.40 \mathrm{Aa}$ & $0.69^{\mathrm{ns}}$ \\
\hline Grain sorghum & 46.89Aab & $48.18 \mathrm{Aa}$ & $41.49 \mathrm{Aa}$ & $0.92^{\text {ns }}$ \\
\hline Sun hemp & $56.84 \mathrm{Aa}$ & $37.83 \mathrm{Ba}$ & $34.77 \mathrm{Ba}$ & $10.43^{*}$ \\
\hline \multirow[t]{2}{*}{ F-test } & $2.71 *$ & $1.28^{\mathrm{ns}}$ & $1.28^{\mathrm{ns}}$ & - \\
\hline & \multicolumn{4}{|c|}{ Soil bulk density $\left(\mathrm{kg} \mathrm{dm}^{-3}\right)$} \\
\hline Corn & $1.51 \mathrm{Aa}$ & $1.47 \mathrm{Aab}$ & $1.45 \mathrm{Aa}$ & $1.71^{\mathrm{ns}}$ \\
\hline Sunflower & $1.45 \mathrm{Bab}$ & $1.53 \mathrm{Aa}$ & $1.48 \mathrm{ABa}$ & $2.90^{*}$ \\
\hline Oilseed radish & $1.41 \mathrm{Ab}$ & $1.45 \mathrm{Aab}$ & $1.45 \mathrm{Aa}$ & $1.84^{\mathrm{ns}}$ \\
\hline Pearl millet & $1.46 \mathrm{Aab}$ & $1.48 \mathrm{Aab}$ & $1.46 \mathrm{Aa}$ & $1.48^{\mathrm{ns}}$ \\
\hline Pigeon pea & $1.43 \mathrm{Aab}$ & $1.44 \mathrm{Aab}$ & $1.41 \mathrm{Aa}$ & $0.35^{\text {ns }}$ \\
\hline Grain sorghum & $1.41 \mathrm{Ab}$ & $1.43 \mathrm{Aab}$ & $1.44 \mathrm{Aa}$ & $0.86^{\mathrm{ns}}$ \\
\hline Sun hemp & $1.40 \mathrm{Ab}$ & $1.40 \mathrm{Ab}$ & $1.44 \mathrm{Aa}$ & $0.37^{\mathrm{ns}}$ \\
\hline F-test & $1.99 *$ & $2.75^{*}$ & $0.75^{\mathrm{ns}}$ & - \\
\hline \multicolumn{5}{|c|}{ 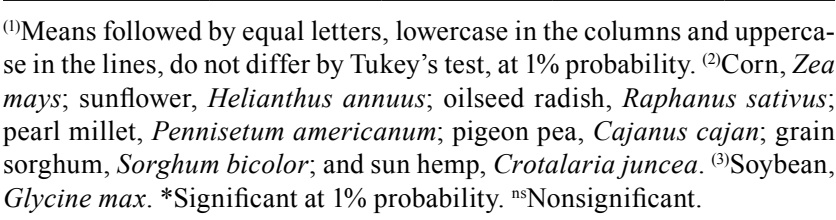 } \\
\hline
\end{tabular}


density and increases total porosity. Corn cultivated as a second crop within soybean/corn rotation, as well as sunflower within continuous corn, increased soil bulk density, probably due to the lower crop residue input on soil surface. Blanco-Canqui et al. (2006) reported that the removal of corn residues increased soil bulk density; however, a year after their addition, at $5 \mathrm{Mg} \mathrm{ha}^{-1}$, soil bulk density decreased by $10-13 \%$, in a silt loam soil, and by $6 \%$ in a clayey loam soil.

\section{Conclusions}

1. Corn (Zea mays) as a summer crop, in monoculture or in rotation with soybean (Glycine max), increases the mean weight diameter (MWD) and tensile strength of soil aggregates in tropical regions.

2. Pearl millet (Pennisetum americanum) and grain sorghum (Sorghum bicolor) as second crops promote MWD of soil aggregates.

3. Soybean/corn rotation as a summer crop, associated with sun hemp (Crotalaria juncea) as a second crop, increases soil physical quality, with positive effects on tensile strength of aggregates and on soil bulk density.

\section{Acknowledgments}

To Fundação de Amparo à Pesquisa do Estado de São Paulo (Fapesp, project No. 08/52560-1), for financial support.

\section{References}

BAYER, C.; MARTIN-NETO, L.; MIELNICZUK, J.; PAVINATO, A.; DIECKOW, J. Carbon sequestration in two Brazilian Cerrado soils under no-till. Soil and Tillage Research, v.86, p.237-245, 2006. DOI: 10.1016/j.still.2005.02.023.

BLANCO-CANQUI, H.; LAL, R. Corn stover removal for expanded uses reduces soil fertility and structural stability. Soil Science Society of America Journal, v.73, p.418-426, 2009. DOI: 10.2136/sssaj2008.0141.

BLANCO-CANQUI, H.; LAL, R. Corn stover removal impacts on micro-scale soil physical properties. Geoderma, v.145, p.335346, 2008. DOI: 10.1016/j.geoderma.2008.03.016.

BLANCO-CANQUI, H.; LAL, R.; POST, W.M.; IZAURRALDE, R.C.; OWENS, L.B. Corn stover impacts on near-surface soil properties of no-till corn in Ohio. Soil Science Society of America Journal, v.70, p.266-278, 2006. DOI: 10.2136/sssaj2005.0137.

CALONEGO, J.C.; ROSOLEM, C.A. Estabilidade de agregados do solo após manejo com rotações de culturas e escarificação.
Revista Brasileira de Ciência do Solo, v.32, p.1399-1407, 2008. DOI: $10.1590 / \mathrm{S} 0100-06832008000400004$.

CRUSCIOL, C.A.C.; COTTICA, R.L.; LIMA, E. do V.; ANDREOTTI, M.; MORO, E.; MARCON, E. Persistência de palhada e liberação de nutrientes do nabo forrageiro no plantio direto. Pesquisa Agropecuária Brasileira, v.40, p.161-168, 2005. DOI: 10.1590/S0100-204X2005000200009.

DEXTER, A.R.; KROESBERGEN, B. Methodology for determination of tensile strength of soil aggregates. Journal of Agricultural Engineering Research, v.31, p.139-147, 1985. DOI: 10.1016/0021-8634(85)90066-6.

ELLERT, B.H.; BETTANY, J.R. Calculation of organic matter and nutrients stored in soils under contrasting management regimes. Canadian Journal of Soil Science, v.75, p.529-538, 1995. DOI: 10.4141/cjss95-075.

FIGUEIREDO, G.C.; SILVA, A.P. da; TORMENA, C.A.; GIAROLA, N.F.B.; OLIVEIRA, S.O.; ALMEIDA, B.G. de. Improvement of a testing apparatus for dynamometry: procedures for penetrometry and influence of strain rate to quantify the tensile strength of soil aggregates. Revista Brasileira de Ciência do Solo, v.35, p.373-387, 2011. DOI: 10.1590/S010006832011000200008

FOLONI, J.S.S.; LIMA, S.L. de; BÜLL, L.T. Crescimento aéreo e radicular da soja e de plantas de cobertura em camadas compactadas de solo. Revista Brasileira de Ciência do Solo, v.30, p.49-57, 2006. DOI: 10.1590/S0100-06832006000100006.

GARCIA, R.A.; ROSOLEM, C.A. Agregados em um Latossolo sob sistema plantio direto e rotação de culturas. Pesquisa Agropecuária Brasileira, v.45, p.1489-1498, 2010. DOI: 10.1590/ S0100-204X2010001200021.

GROSSMAN, R.B.; REINSCH, T.G. Bulk density and linear extensibility. In: DANE, J.H.; TOPP, G.C. (Ed.). Methods of soil analysis: part 4: physical methods. Madison: Soil Science Society of America, 2002. p.201-228. DOI: 10.2136/sssabookser5.4.c9.

KEMPER, W.D.; ROSENAU, R.C. Aggregate stability and size distribution. In: KLUTE, A. (Ed.). Methods of soil analysis: part 1: physical and mineralogical methods. $2^{\text {nd }}$ ed. Madison: American Society of Agronomy, 1986. p.635-660.

MARCELO, A.V.; CORÁ, J.E.; FERNANDES, C.; MARTINS, M. dos R.; JORGE, R.F. Crop sequences in no-tillage system: effects on soil fertility and soybean, maize and rice yield. Revista Brasileira de Ciência do Solo, v.33, p.417-428, 2009. DOI: 10.1590/S0100-06832009000200019.

MARTINS M.R.; ANGERS, D.A.; CORÁ, J.E. Carbohydrate composition and water-stable aggregation of an Oxisol as affected by crop sequence under no-till. Soil Science Society of America Journal, v.76, p.475-484, 2012. DOI: 10.2136/sssaj2011.0110.

MARTINS, M. dos R.; CORÁ, J.E.; JORGE, R.F.; MARCELO, A.V. Crop type influences soil aggregation and organic matter under no-tillage. Soil and Tillage Research, v.104, p.22-29, 2009. DOI: $10.1016 /$ j.still.2008.11.003.

SÁ, J.C. de M.; SÉGUY, L.; TIVET, F.; LAL, R.; BOUZINAC, S.; BORSZOWSKEI, P.R.; BRIEDIS, C.; SANTOS, J.B. dos; HARTMAN, D. da C.; BERTOLONI, C.G.; ROSA, J.; 
FRIEDRICH, T. Carbon depletion by plowing and its restoration by no-till cropping systems in Oxisols of subtropical and tropical agro-ecoregions in Brazil. Land Degradation and Development, v.26, p.531-543, 2015. DOI: 10.1002/ldr.2218.

SANTOS, H.G. dos; JACOMINE, P.K.T.; ANJOS, L.H.C. dos; OLIVEIRA, V.A. de; LUMBRERAS, J.F.; COELHO, M.R.; ALMEIDA, J.A. de; CUNHA, T.J.F.; OLIVEIRA, J.B. de. Sistema brasileiro de classificação de solos. 3.ed. rev. e ampl. Brasília: Embrapa, 2013. 353p.

SEBEN JUNIOR, G. de F.; CORÁ, J.E.; LAL, R. The effects of land use and soil management on the physical properties of an Oxisol in Southeast Brazil. Revista Brasileira de Ciência do Solo, v.38, n.4, p.1245-1255, 2014. DOI: 10.1590/S010006832014000400021.

SEBEN JUNIOR, G.F.; CORÁ, J.E.; FERNANDES, C.; LAL, R. Aggregate shape and tensile strength measurement. Soil Science, v.178, p.301-307, 2013. DOI: 10.1097/ SS.0b013e3182a4a0a6.
SPERA, S.T.; SANTOS, H.P. dos; FONTANELI, R.S.; TOMM, G.O. Integração lavoura e pecuária e os atributos físicos de solo manejado sob sistema plantio direto. Revista Brasileira de Ciência do Solo, v.33, p.129-136, 2009. DOI: 10.1590/S010006832009000100014.

TORMENA, C.A.; ARAÚJO, M.A.; FIDALSKI, J.; IMHOFF, S.; SILVA, A.P. da. Quantificação da resistência tênsil e da friabilidade de um Latossolo Vermelho distroférrico sob plantio direto. Revista Brasileira de Ciência do Solo, v.32, p.943-952, 2008. DOI: $10.1590 /$ S0100-06832008000300004.

UNGARO, M.R.G.; PECHE FILHO, A.; LINO, A.C.L.; DUARTE, A.P. Agregação de Latossolo Vermelho sob diferentes sistemas de preparo do solo, após um único cultivo com girassol. Revista Brasileira de Engenharia Agrícola e Ambiental, v.9, p.229-233, 2005. DOI: $10.1590 /$ S1415-43662005000200013.

YEOMANS, J.C.; BREMNER, J.M. A rapid and precise method for routine determination of organic carbon in soil. Communications in Soil Science and Plant Analysis, v.19, p.1467-1476, 1988. DOI: 10.1080/00103628809368027.

Received on August 30, 2015 and accepted on March 30, 2016 